\title{
RADIOCARBON IMPACT ON A NEARBY TREE OF A LIGHT-WATER VVER-TYPE NUCLEAR POWER PLANT, PAKS, HUNGARY
}

\author{
R Janovics ${ }^{1,2} \bullet Z_{\text {Kern }}^{3,4} \bullet$ D Güttler ${ }^{5}$ L Wacker ${ }^{5}$ I Barnabás ${ }^{6} \cdot M$ Molnár ${ }^{1}$ \\ ABSTRACT. Tree-ring series were collected for radiocarbon analyses from the vicinity of Paks nuclear power plant (NPP) \\ and a background area (Dunaföldvár) for a 10-yr period (2000-2009). Samples of holocellulose were prepared from the wood \\ and converted to graphite for accelerator mass spectrometry (AMS) ${ }^{14} \mathrm{C}$ measurement using the MICADAS at ETH Zürich. \\ The ${ }^{14} \mathrm{C}$ concentration data from these tree rings was compared to the background tree rings for each year. The global decreas- \\ ing trend of atmospheric ${ }^{14} \mathrm{C}$ activity concentration was observed in the annual tree rings both in the background area and in \\ the area of the NPP. As an average of the past $10 \mathrm{yr}$, the excess ${ }^{14} \mathrm{C}$ emitted by the pressurized-water reactor (PWR) NPP to \\ the atmosphere shows only a slight systematic excess $(\sim 6 \%){ }^{14} \mathrm{C}$ in the annual rings. The highest ${ }^{14} \mathrm{C}$ excess was $13 \%$ (in \\ 2006); however, years with the same ${ }^{14} \mathrm{C}$ level as the background were quite frequent in the tree-ring series.
}

\section{INTRODUCTION}

Trees intake carbon mostly from atmospheric $\mathrm{CO}_{2}$ uptake via photosynthesis. The actual radiocarbon isotope ratio of the surrounding air is preserved in their organic materials (Levin et al. 1985). In contrast to several wood compounds (lignin, resins, waxes, etc.), cellulose is not remobilized in tree tissues after formation (Hertelendi and Csongor 1982; Hua et al. 1999). Therefore, changes in the atmospheric ${ }^{14} \mathrm{C}$ activity concentration are preserved in the cellulose of tree rings (Tans et al. 1979; Otlet et al. 1989; Isogai et al. 2002; Mazeika et al. 2008).

${ }^{14} \mathrm{C}$ emitted during the operation of nuclear facilities may increase the ${ }^{14} \mathrm{C}$ content of the local atmosphere. In several published cases, excess ${ }^{14} \mathrm{C}$ was measurable in the annual rings of nearby trees (Dai et al. 1992; Stenström et al. 1996; Mazeika et al. 2008). The Paks nuclear power plant (NPP) has been operating with VVER-440/213 type reactors since 1987. VVER-type nuclear power plants emit ${ }^{14} \mathrm{C}$ in the form of $\mathrm{CO}_{2}$ and hydrocarbons. A significant part of the emission occurs in the form of hydrocarbons that are oxidized later to $\mathrm{CO}_{2}$ in the atmosphere (Veres et al. 1995; Uchrin et al. 1998). In 2000-2005, the mean normalized yearly emission rates from the Paks NPP were 740 $\mathrm{GBq}$ for hydrocarbons and $50 \mathrm{GBq}$ for $\mathrm{CO}_{2}$ (Molnár et al. 2007). The power plant emits ${ }^{14} \mathrm{C}$ mainly via the 130 -m-high stacks. ${ }^{14} \mathrm{C}$ concentration of air in the stacks varied between 80 and $200 \mathrm{Bqm}^{-3}$. Several atmospheric ${ }^{14} \mathrm{C}$ samplers have been installed to monitor the air around the NPP and Interim Spent Fuel Storage Facility (ISFSF). A small excess ${ }^{14} \mathrm{C}\left(5-15 \%\right.$ from $\left.{ }^{14} \mathrm{CO}_{2}\right)$ has been observed at the A4 environmental monitoring station (Figure 1) near the NPP in the prevailing wind direction. Furthermore, there was a serious third-level incident (INES-3, on the basis of International Nuclear and Radiological Event Scale [INES]) on 10 April 2003 in Unit 2 of the Paks NPP. The incident was caused by some damaged and overheated nuclear fuel in the cleaning tank (Aszódi et al. 2010). More than $10^{14} \mathrm{~Bq}$ of noble gas and other radioactive gases were released to the environment through the Unit 2 stack (Hungarian Atomic Energy Agency 2003). The aim of our research is to determine whether the effect of the incident can be detected in the nearby vegetation during normal operation intervals and after the malfunction period in 2003.

\footnotetext{
${ }^{1}$ Institute for Nuclear Research of the Hungarian Academy of Sciences.

${ }^{2}$ Corresponding author. Email: janovics@atomki.hu.

${ }^{3}$ Climate and Environmental Physics, Physics Institute, University of Bern and Oeschger Centre for Climate Change Research, Bern, Switzerland.

${ }^{4}$ Institute for Geology and Geochemistry, MTA Research Center for Astronomy and Earth Sciences, Budapest, Hungary.

${ }^{5}$ Laboratory of Ion Beam Physics, ETH Zürich, Switzerland.

${ }^{6}$ Public Limited Company for Radioactive Waste Management, Hungary.
}

(C) 2013 by the Arizona Board of Regents on behalf of the University of Arizona

Proceedings of the 21st International Radiocarbon Conference edited by A J T Jull \& C Hatté

RADIOCARBON, Vol 55, Nr 2-3, 2013, p 826-832 


\section{$R$ Janovics et al.}

\section{EXPERIMENTAL}

\section{Description of Sampling Area and Sample Handling}

Sampling sites were located near the Paks NPP and the background control site at Dunaföldvár. Paks NPP is situated near the Danube River in southern Hungary $\left(46^{\circ} 35^{\prime} \mathrm{N}, 18^{\circ} 51^{\prime} \mathrm{E}\right)$ (Figure 1). The background sampling point (station B24) is surrounded by an agricultural field near the outskirts of Dunaföldvár, $25 \mathrm{~km}$ north of Paks NPP $\left(46^{\circ} 46^{\prime} \mathrm{N}, 18^{\circ} 56^{\prime} \mathrm{E}\right)$. The dominant wind direction at B24 is from the northwest. Thus, the atmospheric ${ }^{14} \mathrm{C}$ level at B24 should not be influenced by Paks NPP (Molnár et al. 2007).

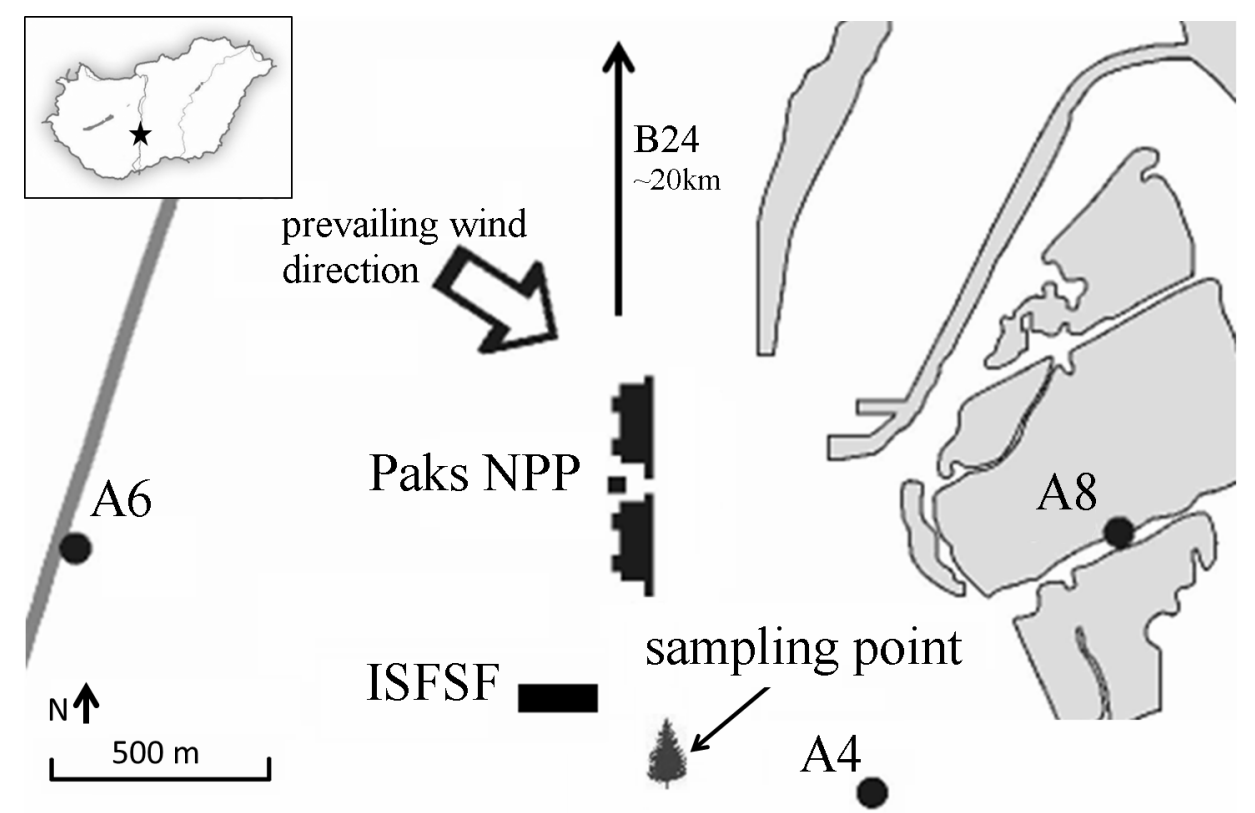

Figure 1 Map of the sampling area: A4, A6, and A8 are the environmental monitoring stations; NPP: Paks nuclear power plant; ISFSF: Interim Spent Fuel Storage Facility.

Sampling was carried out in October 2010 at the end of the local growing season. Samples were collected from $400 \mathrm{~m}$ south of the power plant and $250 \mathrm{~m}$ southeast from the ISFSF. Healthy Scots pine (Pinus sylvestris L.) trees were selected for sampling. Despite the fact that pine is not an indigenous species in the area, this conifer was selected because evergreen species are better biomonitors for airborne pollution due to their larger leaf area and permanent foliage (Cutter and Guyette 1993). Multiple cores (5-6) were extracted from selected trees using an increment borer (Haglö ${ }^{\circledR}$ ) (Figure 2). The sampling height was the standard breast-height. Increment cores were slightly trimmed perpendicular to fibers using a Teflon ${ }^{\circledR}$-coated razor blade. First, tree-ring sequences extracted from the same tree were carefully cross-checked under a binocular microscope, then samples from different trees were compared (Stokes and Smiley 1968). A LINTAB digital-positioning table and TSAP Win 0.55 software (Rinn 2005) were used to measure the annual ring widths with a precision of $0.01 \mathrm{~mm}$, as well as for cross-dating the growth series by graphical comparison against each other. The results were checked for missing rings and dating errors using COFECHA software (Holmes 1983). Finally, tree rings from each core were detached using a scalpel, inspected under a binocular microscope, and subsamples belonging to the same annual increment were pooled. Cross- 
dating and tree-ring separation were done by a trained dendrochronologist using the facilities of the Budapest Tree-ring Laboratory (Eötvös University, Dept. of Palaeontology; Kázmér and Grynaeus 2003).

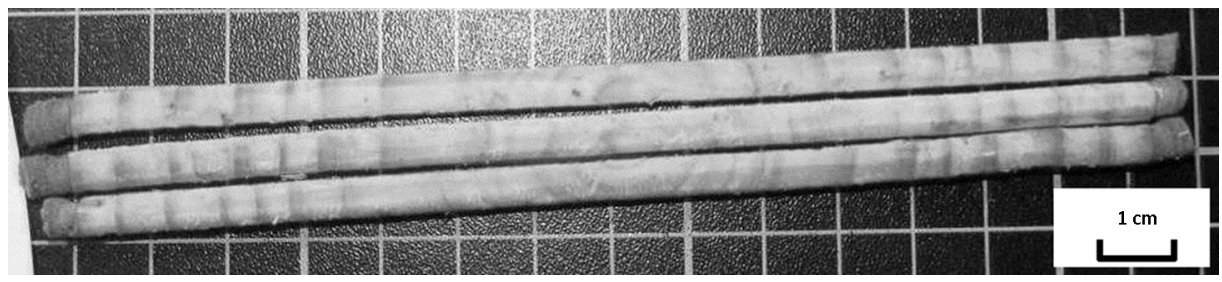

Figure 2 A set of increment cores extracted from a Pinus sylvestris specimen before ring separation

In order to remove disturbing wood compounds, the $\alpha$-cellulose was prepared from annual rings at the ETH Zürich. The annual rings from 2000 to 2009 were chopped into small pieces. Preparation was performed according to the BABAB (base-acid-base-acid-bleaching) method (Němec et al. 2010). As a first step, the sample was soaked in $4 \% \mathrm{NaOH}$ overnight. The samples were then treated with $4 \% \mathrm{HCl}$ for $1 \mathrm{hr}$. The third step was soaking in $4 \% \mathrm{NaOH}$ for $1.5 \mathrm{hr}$ again and a final soaking in $4 \% \mathrm{HCl}$ for $1 \mathrm{hr}$. Between each step, samples were heated to $75^{\circ} \mathrm{C}$ and rinsed to neutral with demineralized water. After the last washing step, $5 \% \mathrm{NaClO}_{2}$ was added to bleach the samples and samples were acidified to $\mathrm{pH} 2$ with $\mathrm{HCl}$. Bleaching was done for several hours until the cellulose was pure white (Němec et al. 2010; Gaudinski et al. 2005). After the bleaching process, the sample was washed to $\mathrm{pH} 4$, and dried at $75^{\circ} \mathrm{C}$ in an oven. All of chemical agents used were of analytical grade.

\section{Graphitization and AMS Measurement}

The dried holocellulose samples were graphitized by an EA-AGE (Elemental Analyser coupled with Automatic Graphitisation Equipment). $\mathrm{CO}_{2}$ gas generated from combustion by the EA is adsorbed on the zeolite trap of the AGE and is then flushed into the reaction cell. Based on the sample amount, the AGE automatically doses the proper quantity of $\mathrm{H}_{2}$ gas and graphitizes the sample (Wacker et al. 2010a). The ${ }^{14} \mathrm{C}$ measurements were performed with the MICADAS AMS at ETH Zürich (Synal et al. 2007; Wacker et al. 2010b). Measurement time and conditions were set to collect at least 500,000 net counts for every single target and the NPP and B24 background tree-ring pairs followed each other in the same sample magazine. The overall measurement uncertainty for each sample was below $3 \%$, including normalization, background subtraction, and counting statistics.

\section{RESULTS AND DISCUSSION}

The measurement results are given in Table 1 and were corrected for decay of the standard and for $\delta^{13} \mathrm{C}$, calculated to the year of formation of the given tree rings as described by Stuiver and Polach (1977). The ${ }^{14} \mathrm{C}$ activity concentration of the tree rings at both sampling points decreased by more than $44 \%$ in the course of the investigated period as a result of the decline of the ${ }^{14} \mathrm{C}$ signal due to atmospheric nuclear testing. The ${ }^{14} \mathrm{C}$ atmospheric concentration has been continuously decreasing almost exponentially following the Comprehensive Test Ban Treaty because of the buffering effect of the biosphere and the oceans (Levin et al. 1985; Povinec et al. 1986; Hua et al. 2000; Levin and Kromer 2004; Mazeika et al. 2008).

The decrease in atmospheric ${ }^{14} \mathrm{C}$ concentration can be described by an exponential function (Hua et al. 1999; Rakowski et al. 2010). Results from tree-ring series of Paks NPP and the background station also fit well on an exponential curve, with correlation coefficients of 0.95 and 0.96 , respectively. 


\section{R Janovics et al.}

Table $1{ }^{14} \mathrm{C}$ activity values of pine tree rings at the B24 (background) and Paks NPP locations $( \pm 3 \% ; 1 \sigma)$.

\begin{tabular}{lllc}
\hline Origin year of tree rings & B24 (\%) & Paks NPP (\%) & Paks NPP-B24 (\%) \\
\hline 2000 & 86 & 87 & 1 \\
2001 & 79 & 85 & 6 \\
2002 & 71 & 77 & 6 \\
2003 & 68 & 74 & 6 \\
2004 & 59 & 67 & 8 \\
2005 & 54 & 53 & -1 \\
2006 & 45 & 58 & 13 \\
2007 & 45 & 50 & 5 \\
2008 & 40 & 51 & 11 \\
2009 & 42 & 42 & 0 \\
\hline
\end{tabular}

There is no significant ${ }^{14} \mathrm{C}$ excess in 3 different years of the decade studied (2000, 2005, and 2009). The sample from Paks appears to have been planted in a nursery garden far from Paks NPP during the first couple of years after germination. The innermost ring from the increment core (2000) extracted at breast height might represent the last year of this juvenile growing period. For this reason, the data of the first year (2000) were ignored from the NPP impact study. The reason for the very low NPP effect in 2005 and 2009 is not clear. Between 2009 and 2010 , the ${ }^{14} \mathrm{C}$ concentrations of the tree rings near Paks NPP were slightly, but systematically, higher by $5.5 \pm 1.4 \%$ o than the samples taken at the background sampling site at Dunaföldvár.

In Molnár et al.'s (2007) study, air samples were taken at the A4 atmospheric ${ }^{14} \mathrm{C}$ sampling station during the vegetation period (April-October). Between 2000 and 2005, the average ${ }^{14} \mathrm{C}$ excess in the $\mathrm{CO}_{2}$ fraction was $12 \pm 5 \%$, while for the total carbon fraction, including hydrocarbons, the excess was $\sim 67 \%$. The observed significantly lower effect in the tree rings probably means that ${ }^{14} \mathrm{C}$ emitted mostly in the form of hydrocarbons by the NPP, and is only incorporated to a very limited extent into the tissues of the nearby trees in the vicinity of the NPP.

The highest excess ${ }^{14} \mathrm{C}$ concentrations were observed in 2006 and 2008, when the excess ${ }^{14} \mathrm{C}$ concentration in the Paks tree rings slightly increased ( 12\%) compared to the background (Figure 3 ). These values are almost twice as high as the average of the other values. However, the effects of a cleaning tank incident of Paks NPP in 2003 were not seen in the tree rings investigated.

The tree-ring ${ }^{14} \mathrm{C}$ data are compared with the atmospheric ${ }^{14} \mathrm{C}$ values of the Jungfraujoch mountain station (Levin et al. 2008) in Figure 4. Levin's data are measured values between 1986 and 2007, but have extrapolated monthly values up to 2009. In order to correct for the growth period of a pine tree, Levin's data from the months April to October in each year were averaged and plotted (see Figure 4). The tree-ring ${ }^{14} \mathrm{C}$ values were always close to the Jungfraujoch curve obtained for the productive period of the vegetation cycle. In most cases, the tree-ring-derived values at the background station are the same as the Jungfraujoch atmospheric ${ }^{14} \mathrm{C}$ data, while those from the vicinity of Paks NPP are generally above the Jungfraujoch curve. The average excess of the tree from B24 to the Jungfraujoch air ${ }^{14} \mathrm{C}$ is less than $2 \%$, while for the NPP tree it is $7 \pm 1 \%$. 


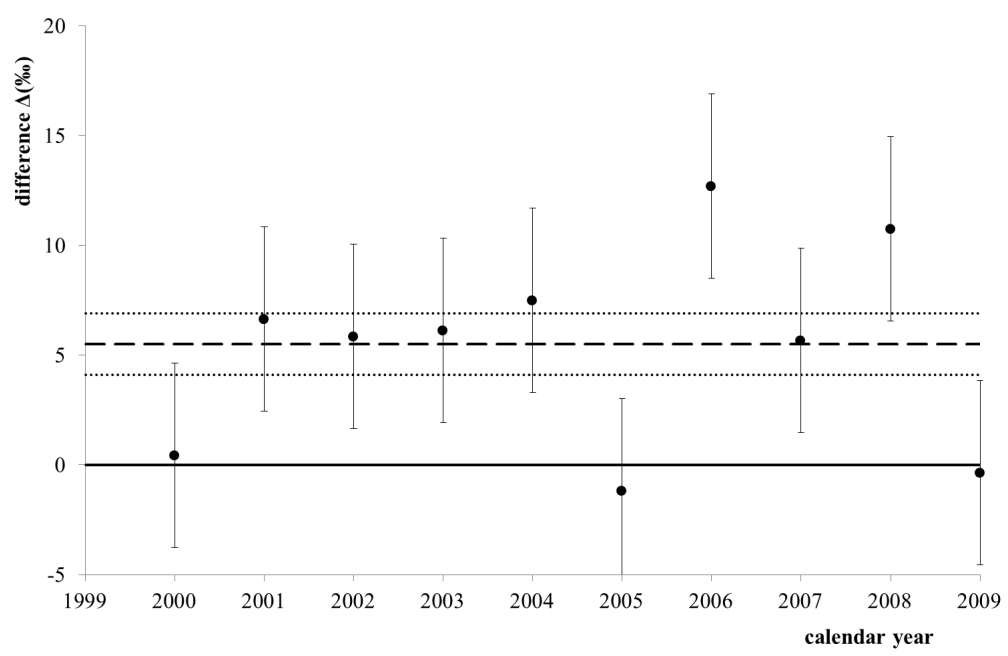

Figure 3 Change in excess ${ }^{14} \mathrm{C}$ concentration for tree rings at Paks NPP (continuous line at zero shows the background level, dashed line and dotted lines shows the average excess and the uncertainty band, respectively.)

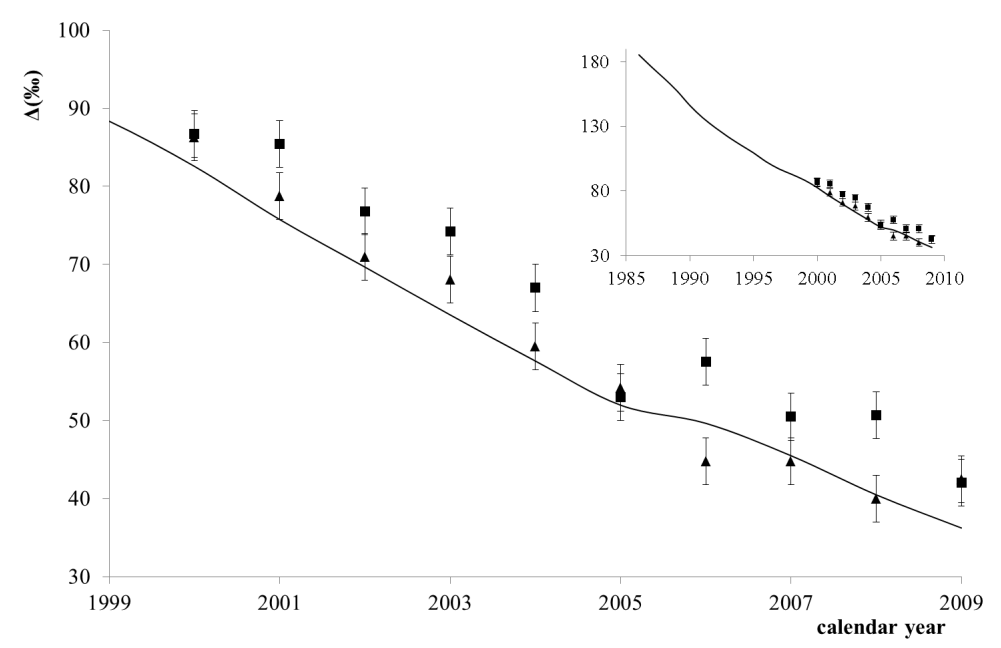

Figure 4 Change in ${ }^{14} \mathrm{C}$ concentration for tree rings at B24 (triangles) and Paks NPP (squares) from 2000 to 2009 and fit on the decreasing trend of atmospheric ${ }^{14} \mathrm{C}$ concentration at Jungfraujoch (curve) (Levin et al. 2008).

\section{CONCLUSION}

The ${ }^{14} \mathrm{C}$ concentrations of tree rings sampled near Paks NPP exceed those from the background station in most cases; however, this difference is small. The cleaning tank incident in 2003 was not observable in the tree nearby Paks NPP. Tree-ring-based environmental ${ }^{14} \mathrm{C}$ reconstruction may be significant in any posterior survey of excess ${ }^{14} \mathrm{C}$ emissions from NPP, even in the case of PWR power plants. The continuous global decrease of atmospheric ${ }^{14} \mathrm{C}$ concentration can be observed in the tree rings of both sampling sites, and these values fit well both in order of magnitude and in comparison to the data of the Jungfraujoch atmospheric ${ }^{14} \mathrm{C}$ station. The contribution of Paks NPP to the 


\section{$R$ Janovics et al.}

${ }^{14} \mathrm{C}$ content of the trees was on average $5.5 \pm 1.4 \%$ above background for the 10 -yr period investigated. The highest ${ }^{14} \mathrm{C}$ excess was $13 \pm 4 \%$ in 2006 . Thus, ${ }^{14} \mathrm{C}$ emitted by the NPP to the atmosphere causes only a minor increment in the ${ }^{14} \mathrm{C}$ content of the annual rings of the nearby trees. This is a logical consequence of the observation that PWR-type NPPs emit ${ }^{14} \mathrm{C}$ mainly in the form of hydrocarbons and not carbon dioxide.

\section{ACKNOWLEDGMENTS}

We thank László Papp for the help in sampling and Ms Magdolna Mogyorósi helping with sample preparation. The project was supported by the Hungarian Scientific Research Fund (MB08-A 81515). ZK expresses thanks for support from ISO-TREE (Sciex code: 10.255.) and "Lendület" program of the Hungarian Academy of Sciences (LP2012-27/2012).

\section{REFERENCES}

Aszódi A, Légrádi G, Boros I. 2010. Causes, course and consequences of fuel damage incident in the Paks NPP, 2003 and connecting thermal-hydraulic analyses. Nuclear Engineering and Design 240(3):550-67.

Cutter BE, Guyette RP. 1993. Anatomical, chemical and ecological factors affecting tree species choice in dendrochemistry studies. Journal of Environmental Quality 22(3):611-9.

Dai K-M, Qian Y, Fan CY. 1992. Bomb-produced ${ }^{14} \mathrm{C}$ in tree rings. Radiocarbon 34(3):753-6.

Gaudinski JB, Dawson TE, Quideau S, Schuur EAG, Roden JS, Trumbore SE, Sandquist DR, Oh SW, Wasylishen RE. 2005. Comparative analysis of cellulose preparation techniques for use with ${ }^{13} \mathrm{C},{ }^{14} \mathrm{C}$, and ${ }^{18} \mathrm{O}$ isotopic measurements. Analytical Chemistry 77(22): $7212-24$.

Hertelendi E, Csongor E. 1982. Anthropogenic ${ }^{14} \mathrm{C}$ excess in the troposphere between 1951 and 1978 measured in tree rings. Radiochemical and Radioanalytical Letters 56(2):103-10.

Holmes RL. 1983. Computer-assisted quality control in tree-ring dating and measurements. Tree-Ring Bulletin 43:69-75.

Hua Q, Barbetti M, Worbes M, Head J, Levchenko VA. 1999. Review of radiocarbon data from atmospheric and tree ring samples for the period AD 1945-1997. IAWA Journal 20(3):261-83.

Hua Q, Barbetti M, Jacobsen GE, Zoppi U, Lawson EM. 2000. Bomb radiocarbon in annual tree rings from Thailand and Australia. Nuclear Instruments and Methods in Physics Research B 172(1-4):359-65.

Hungarian Atomic Energy Agency (HAEA). 2003. Report to the Chairman of the Hungarian Atomic Energy Commission on the Authority's investigation of the incident at Paks Nuclear Power Plant on 10 April 2003. Identification number of the event: 1120, May 23, 2003.

Isogai K, Cook GT, Anderson R. 2002. Reconstructing the history of ${ }^{14} \mathrm{C}$ discharges from Sellafield: part $1-$ atmospheric discharges. Journal of Environmental Radioactivity 59(2):207-22.
Kázmér M, Grynaeus A. 2003. The Budapest Tree-Ring Laboratory. Association for Tree-Ring Research, Newsletter 1:5-6.

Levin I, Kromer B. 2004. The tropospheric ${ }^{14} \mathrm{CO}_{2}$ level in mid-latitudes of the Northern Hemisphere (19592003). Radiocarbon 46(3):1261-72.

Levin I, Kromer B, Schoch-Fischer H, Bruns M, Münnich M, Berdau D, Vogel JC, Münnich K. 1985. 25 years of tropospheric ${ }^{14} \mathrm{C}$ observations in central Europe. Radiocarbon 27(1):1-19.

Levin I, Hammer S, Kromer B, Meinhardt F. 2008. Radiocarbon observations in atmospheric $\mathrm{CO}_{2}$ : determining fossil fuel $\mathrm{CO}_{2}$ over Europe using Jungfraujoch observations as background. Science of the Total Environment 391(2-3):211-6.

Mazeika J, Petrosius R, Pukiene R. 2008. Carbon-14 in tree rings and other terrestrial samples in the vicinity of Ignalina Nuclear Power Plant, Lithuania. Journal of Environmental Radioactivity 99(2):238-47.

Molnár M, Bujtás T, Svingor E, Futó I, Světlík I. 2007. Monitoring of atmospheric excess ${ }^{14} \mathrm{C}$ around Paks Nuclear Power Plant, Hungary. Radiocarbon 49(2): 1031-43.

Němec M, Wacker L, Hajdas L, Gäggeler H. 2010. Alternative methods for cellulose preparation for AMS measurement. Radiocarbon 52(2-3):1358-70.

Otlet RL, Longley H, Walker AJ. 1989. Measurements of carbon-14 in tree-rings from trees growing in the Sellaeld area. Studies of Environmental Radioactivity in Cumbria, Part 13, AERE R 12362. United Kingdom Atomic Energy Authority, Harwell, Didcot, UK.

Povinec P, Chudy M, Sivo A. 1986. Anthropogenic radiocarbon: past, present and future. Radiocarbon 28(2A):668-72.

Rakowski A, Nakamura T, Pazdur A, Charro E, Villanueva JLG, Piotrowska N. 2010. Radiocarbon concentration in modern tree rings from Valladolid, Spain. Nuclear Instruments and Methods in Physics Research B 268(7-8):1110-2.

Rinn F. 2005. TSAP Reference Manual. Heidelberg. 110 p. 
Stenström K, Riandsson B, Riellborg R, Wiebert A, Skog G. 1996. Environmental levels of carbon-14 around a Swedish nuclear power plant measured with accelerator mass spectrometry. Nuclear Instruments and Methods in Physics Research B 113(1):474-6.

Stokes MA, Smiley TL. 1968. An Introduction to TreeRing Dating. Chicago: University of Chicago Press. $73 \mathrm{p}$.

Stuiver M, Polach H. 1977. Discussion: reporting of ${ }^{14} \mathrm{C}$ data. Radiocarbon 19(3):355-63.

Tans PP, De Jong, AFM, Mook WG. 1979. Natural atmospheric ${ }^{14} \mathrm{C}$ variation and the Suess effect. Nature 280(5725):826-8.

Synal H-A, Stocker M, Suter M. 2007. MICADAS: a new compact radiocarbon AMS system. Nuclear Instruments and Methods in Physics Research B 259(1): 7-13.

Uchrin G, Hertelendi E, Volent G, Slavik O, Morávek J,
Kobal I, Vokal B. $1998 .{ }^{14} \mathrm{C}$ measurements at PWRtype nuclear power plants in 3 middle European countries. Radiocarbon 40(1):439-46.

Veres M, Hertelendi E, Uchrin G, Csaba E, Barnabas I, Ormai P, Volent G, Futó I. 1995. Concentration of radiocarbon and its chemical forms in gaseous effluents, environmental air, nuclear waste and primary water of a pressurized water reactor power plant in Hungary. Radiocarbon 37(2):497-73.

Wacker L, Němec M, Bourquin J. 2010a. A revolutionary graphitisation system: fully automated, compact and simple. Nuclear Instruments and Methods in Physics Research B 268(7-8):931-4.

Wacker L, Bonani G, Friedrich M, Hajdas I, Kromer B, Němec M, Ruff M, Suter M, Synal H-A, Vockenhuber C. 2010b. MICADAS: routine and high-precision radiocarbon dating. Radiocarbon 52(2):252-62. 